\section{OPERATIONAL RESEARCH IN THE RESEARCH ASSOCIATIONS}

$\mathrm{W}$ HAT is 'operational research' ? Is it an activity of major importance to industry ? Can it be carried out effectively by co-operative organisations such as research associations ? How does one set about organising operational research ? These questions were examined at a conference on January 13 and 14 attended by representatives of most of the research associations and of a number of establishments of the Department of Scientific and Industrial Research. The conference was organised by the Committee of Directors of Research Associations under the chairmanship of Mr. B. H. Wilsdon, and was held at Ashorne Hill, through the courtesy of the British Iron and Steel Federation. The conference showed that it was possible to make a reasonably clear definition of the subject, and that operational research in one form or another had proceeded with growing emphasis in certain of the research associations very successfully for a considerable number of years. The research associations generally find themselves very suitably placed for an extension of this type of activity, in view of the wideness of the fields they survey and the close contacts they have with the executives in the industries they serve.

It was desirable to obtain first a general form of words and then to follow this by a consideration of the various factors that make up what might be called 'Operational Research'. The discussion was opened by Sir Charles Goodeve, who proposed a definition based on that put forward originally by Dr. Charles Kittel ${ }^{1}$. After some discussion, the following amended form was considered accurate enough for most purposes :

Operational Research is the use of the scientific method in providing executive departments with a quantitative basis for decisions regarding the operations under their control.

The most problematical part of the definition was in the scope associated with the word 'operations'. In general, it was considered desirable to keep this scope as wide as possible, ranging from the operations in ordinary production engineering to policy matters associated with consumer needs, national economic positions, etc. The chief difficulty appeared to be in drawing a line between process or equipment research and operational research, and it was clear that any attempt to draw a sharp line would be artificial and probably harmful. The difference between 'process' and 'operational' research comes down largely to one of direction of approach. The operational research worker starts with the overall picture and may study individual processes in relation to the whole picture, whereas the process research worker is more concerned with developing certain processes to the highest pitch of efficiency in relation to other parallel or following processes. In addition, there is a difference in degree in that the operational research worker more often has to rely on observations of happenings over which he has no control, whereas the process research worker can generally carry out deliberate experiments with at least a substantial degree of physical control. The operational research worker much more frequently has to deal with human factors, market conditions and the many other factors troubling men in executive positions.

Dr. F. C. Toy, director of the British Cotton Industry Research Association, which organisation has undoubtedly been among the pioneers in this type of work, opened the second session of the conference. He said that, judging by his own experience, operational research should form an integral part of the activities of a research association. It can obtain a comprehensive picture for the whole industry by a collection of data from individual firms, which can be summarized by a statistical digest and a general report. By feeding back this digest to all firms, together with a special confidential report to each individual firm, the executives concermed can see their own position in the light of a complete and accurate background. These reports of ten act simply by stimulating managers to look again at problems or deficiencies already known to exist. This method has proved to be a much quicker way of improving efficiency than the old one of waiting for economic factors to bring into successful prominence the more efficient plants. These studies can also bring out quantitative information on the factors affecting an industry as a whole, and thus aid in determining the right policies for the industry. This is an especially important point in these days when the Government has to deal with many contending issues.

Dr. Toy discussed the prospects of operational research being carried out by organisations other than research associations. Individual firms and professional industrial consultants are limited to studies inside the confine of a particular works; but they can obviously be helped by the wider picture provided by the research associations. The universities and technical colleges are unsuitable for this type of work, but they play a major part in training personnel. The trade federations have a wide picture of the commercial side of each industry; but their lack of technical knowledge and of scientific atmosphere puts a severe limitation on their activities. However, research associations should work in closely with the trade federations, since many of the executive decisions have to be made by such bodies. There may be special instances where operational research should be carried out in industry by Government teams; but if this is done widely in industries served by research associations, it means duplication of effort. In addition, managements are more ready to co-operate with people in an organisation belonging to their own industry than with those who may be looked upon as Government investigators.

All these arguments supported Dr. Toy's contention that, because of the scientific atmosphere, complete impartiality, close contact with industry, with other research organisations and with Government departments, and because of the confidence placed in them by management and operatives, the research associations are the most suitable bodies to carry out operational research in industry.

Mr. A. T. Green, director of the British Ceramics Research Association, pointed out that operational research methods are of particular value in the older industries where the processes are based on traditional methods developed by subsequent experience. $\mathrm{He}$ referred to the detailed works surveys carried out for the National Brick Advisory Council. These give valuable indications of the labour used and of the minimum requirements under a wide variety of manufacturing conditions.

Dr. S. Whitehead, director of the British Electrical and Allied Industries Research Association, spoke about operational research in fields ranging from high-power transmission to radio interference, and emphasized that operational studies frequently pro- 
vide certain links in a chain of deduction of which the remainder are supplied by science and engineering.

Mr. H. Bradley, director of the British Boot, Shoe and Allied Trades Research Association, described the extensive surveys made into the fittings of shoes, based on analyses of measurements of some thousands of feet. For example, most factory-made women's shoes are produced in what are known as singlefitting ranges, that is, each size or half-size of length is made in only one girth. It has always been the practice in the industry to add $\frac{1}{4}$ in. in girth for each successive size. How this interval was arrived at nobody knows, and the analyses of foot measurements showed the correct interval to be $3 / 20$ in.; or 40 per cent less. The practical effect of this on the fitting properties of shoes, particularly the extreme sizes, is considerable, and the Research Association's 'precision grading' based on the new girth interval is having great commercial success.

Mr. D. J. Bishop, of the British Iron and Steel Research Association, showed how a large part of the research programme of that Research Association is continually under study by the operational research team with the object of providing those concerned with the framing of that programme with adequate information, so that research can be focused on problems the solution of which is likely to produce the greatest economic advantage to the steel industry. This is a case where operational research is used at a 'strategic level' to guide research policy.

It was clear from the points raised by numerous speakers that, despite the large volume of operational research already proceeding in industry in Great Britain, many obstacles would have to be overcome before the desired wide application could be attained. In some industries, the firms' problems are so diverse that wide approaches or comparisons are of little value. Also, some industries have been built up and owe their strength to keen competition between firms. Mr. Wilsdon pointed out that, in operational research within an industry, it is essential to take into account variation in the quality of the product, which must be associated in some way with the expenditure of energy in the operations studied in order to provide a comparable basis for executive decisions. Thus criteria such as operations per man-hour or the like might be positively dangerous unless there are good grounds for assuming that the quality of the product is the same throughout. It is clear, therefore, that different industries are likely to adopt operational research to different extents.

On the other hand, as was pointed out by various speakers, there never has been a more favourable opportunity for an extension of operational research. With the present 'sellers' market', competition is at a minimum and co-operation at a maximum. Organised labour, which has always had to look first for security of employment, is able now to take a broader view and consider efficiency of employment.

The discussion on organisation and staff was opened by Mr. Tippett, of the British Cotton Industry Research Association. He considered that a separate operational research team is desirable if the subject is to be treated with the seriousness and comprehensiveness its importance requires. The separate team requires close contact with the management side of industry, with the trade associations, Government departments, etc., and also should have close contact with the field observational work. The team should be staffed with men chosen first of all for their ability to view things widely. They should have good scientific ability, and need to acquire technical knowledge of the industry they serve; but they need not have any particular specialized qualifications. The knowledge of statistics required for most of the work is not very great, although it is desirable to have at least one first-class statistician in a team. It is very important that members of the operational research team should be able to talk to managers, foremen and operators, and to get on well with everyone in the factory.

The objects of operational research which have been or could be carried out by the research associations can be summarized as follows: (1) to increase production per man hour, per unit of equipment, or per unit of fuel ; (2) to improve quality and suitability of products ; (3) to improve the basis for decisions regarding the application of science ("bridging the gap') ; (4) to make accurate studies of consumer or market problems, that is, scientific studies in market research; (5) to aid in finding the optimum degree of standardization for any particular field of production; (6) to aid in the planning of research programmes.

The proceedings concluded by short talks by Dr. W. L. Francis, of the Department of Scientific and Industrial Research, and Dr. Alexander King, director of the scientific secretariat, Lord President's Office, on operational research activity and interest in Government departments.

C. F. G.

\footnotetext{
${ }^{1}$ Kittel, C., Science, 105 (Feb. 7, 1947). See also Goodeve, C. F. Nature, March 13, 1948, p. 377 , for general article on operational research.
}

\section{FOOD PRODUCTION FROM HILL GRAZING LAND}

\author{
By DR. GEORGE DUNLOP \\ West of Scotland College of Agriculture
}

$T$ HE Minister of Agriculture has pointed out that while before the War, for Great Britain as a whole, less than 40 per cent of our food, on a calorie basis, was produced at home, this figure in 1946 had increased to almost 70 per cent.

The land of Scotland may be classified under the headings of :

(1) Farm land: arable and grass land.

(2) Hill pasture.

(3) Other land: deer forests, woodlands, etc.

Sir John Russell has estimated that one acre of farmland produces sufficient food for one person. The population of Scotland is about five million and the arable and grassland acreage about the same figure. This indicates that Scotland is self-supporting in food. It is true that tropical foods, such as grapefruit, bananas, etc., are imported; but on the other hand a good proportion of the arable acreage is devoted to the production of seed potatoes which are transported to England and abroad. Similarly, surplus milk on occasion has found a market south of the border.

The agricultural returns show that there are approximately ten million acres of hill land in Scotland devoted to hill sheep farming. The agricultural production of this type of land will be discussed later. The remaining four million acres may be classed, so far as agricultural production is concerned, as 'waste', 